\title{
PENGGUNAAN HAK ANGKET OLEH DPR RI DALAM MENGAWASI KEBIJAKAN PEMERINTAH
}

\author{
Oleh: Subardjo \\ Fakultas Hukum Universitas Ahmad Dahlan \\ E-mail: subardjo_fhuad@yahoo.com
}

\begin{abstract}
Inquiry rights is the right of Parliament to conduct an investigation on the implementation of a law or government policies relating to the important things, strategically, and impacted people's lives, nation, and state that allegedly contrary to the legislation. The rights, in its use is different between Law No. 6 of 1954 and Law No. 27 of 2009, both the implementation and the effectiveness in controlling government policy.This paper used sociological juridical approach by outlining the legislation related to inquiry rights and analyzing sociological aspect of the use of the inquiry rights by the members of Republic Indonesia Parliament.In conclusion, the inquiry rights of Parliament members has been used normatively and tend to be political, they just want to be safe by sheltering under the government power to get something or sheltering on behalf of the people to draw sympathy, so that in the next election they could boost the votes.
\end{abstract}

Keywords: Inquiry rights, Government policy.

\section{A. LATAR BELAKANG}

Pada sejarah lembaga perwakilan di Indonesia mulai sejak tahun 1945 sampai tahun 2011 sekarang ini dapat dihitung, berapa kali Lembaga Perwakilan tersebut mengajukan hak menyelidiki atau hak angketnya untuk mengontrol dan mengawasi kebijakan pemerintah yang berkuasa pada saat itu. Secara normatif hak angket diatur dalam UUD 1945 pasal 20A ayat (2), kemudian diperjelas lagi dengan Undang-undang No 27 Tahun 2009. Jauh sebelum kedua peraturan normatif tersebut lahir pada masa orde lama, yaitu masa parlementer, telah dikeluarkan Undang-Undang mengenai hak angket yaitu UU No 6 Tahun 1954 tentang Hak Angket. Meskipun undang-undang ini berasal dari zaman sistem pemerintahan parlementer di bawah UUD Sementara Ta-hun 1950, tetapi sampai sekarang masih digunakan. Mahkamah Konstitusi melalui putusannya tanggal 26 Maret 2004 menegaskan, UU Nomor 6 Tahun 1954 itu masih berlaku berdasarkan ketentuan Pasal I Aturan Peralihan UUD 1945. tidak ada keragu-an apa pun bagi DPR menggunakan ketentuan-ketentuan dalam UU Nomor 6 Tahun 1954 itu untuk melaksanakan hak angket DPR. Kedua peraturan normatif tersebut memiliki cara dan syarat yang berbeda dalam mekanisme pengajuan hak angket ter-sebut.

Faktor atau alasan mengapa hak angket tersebut diajukan, menjadi penyebab utama perbedaan dari kedua mekanisme tersebut. Adapun mekanisme pengajuan hak angket yang diatur dalam UU No. 6 Tahun 1954 tentang Hak Angket adalah sebagai berikut: 
1. Usul untuk mengadakan angket dimajukan dengan tertulis oleh sekurang-kurangnya 10 orang anggota Dewan Perwakilan Rakyat.

2. Putusan untuk mengadakan angket diambil dalam suatu rapat terbuka Dewan Perwakilan Rakyat, yang diadakan sesudah usul itu dibicarakan dalam seksi atau seksi-seksi yang bersangkutan, dan putusan itu memuat perumusan yang teliti tentang hal yang akan diselidiki.

3. Putusan selengkapnya, termaksud diumumkan dengan resmi dalam Berita Negara, sesuai dengan risalah Dewan Perwakilan Rakyat yang bersang-kutan

4. Semenjak pengumuman tersebut, semua warga negara Republik Indonesia dan semua penduduk serta orang-orang lain yang berada dalam wilayah Republik Indonesia diwajibkan memenuhi panggilan-panggilan Panitia Angket, dan wa-jib pula menjawab semua pertanyaan-pertanyaannya dan memberikan keterangan-keterangan selengkapnya.

5. Saksi-saksi dan ahli-ahli datang kepada Panitia Angket, baik dengan suka-rela atas panggilan tertulis maupun karena dipanggil dengan perantaraan juru sita.

6. Jurusita pada Pengadilan Negeri menjalankan panggilan saksi-saksi atau ahli-ahli atas perintah Panitia Angket langsung atau atas perintah jaksa berhubung dengan permintaan Panitia Angket.

7. Panggilan saksi-saksi atau ahli-ahli disainpaikan kepada orangnya sendiri atau di tempat tinggalnya, sekurang-kurangnya tujuh hari sebelum hari pemeriksaan.

8. Catatan tertulis dari keterangan-keterangan atau berita-berita yang diberikan oleh saksi atau ahli dibacakan kepada mereka atau diberikan kepadanya untuk dibacanya dan sesudahnya ditanda tangani oieh saksi atau ahli yang bersang-kutan. Dalam hal saksi atau ahli itu tidak dapat menulis maka catatan tersebut dibubuhi cap jempol.

9. Segala pemeriksaan oleh Panitia Angket dilakukan dalam rapat tertutup.

10. Anggota-anggota Panitia Angket wajib merahasiakan keterangan-keterangan yang diperoleh dalam pemeriksaan, sampai ada keputusan lain yang diambil oleh rapat pleno tertutup Dewan Perwakilan Rakyat yang diada-kan khusus untuk itu.

11. Apabila Panitia Angket menganggap perlu untuk mendengar orangorang, yang berdiam di luar negeri, sebagai saksi atau ahli, maka pertanyaan-per-tanyaan yang diinginkan penjawabannya dapat diberitahukan dengan ter-tulis oleh Panitia Angket kepada Menteri yang bersangkutan yang mem-bantu dipenuhinya pertanyaan-pertanyaan itu dengan perantaraan Per-wakilan Indonesia di luar negeri, dan apabila pertanyaan-pertanyaan itu mengenai soal luar negeri kepada Menteri Luar Negeri yang membantu di-penuhinya pertanyaan-pertanyaan itu dengan perantaraan Perwakilan Luar Negeri. Apabila pertanyaanpertanyaan yang diberitahukan itu ha-rus dijawab oleh pegawai-pegawai 
atau anggota-anggota tentara dari segala pangkat dan menteri yang bersangkutan berpendapat, bahwa ke-pentingan Negara tidak mengijinkan penjawabannya, maka hal ini di-beritahukan kepada Panitia Angket. Dalam hal ini berlaku ketentuan pasal 20 ayat 4 .

12. Dengan tidak mengurangi ketentuan yang tersebut, maka segala keterangan yang diberikan kepada Panitia Angket tidak dapat dipergunakan sebagai bukti dalam peradilan terhadap saksi atau ahli itu sendiri yang memberikan ketera-ngan atau terhadap orang lain.

13. Kekuasaan dan pekerjaan Panitia Angket tidak tertunda oleh penutupan sidang-sidang atau pembubaran Dewan Perwakilan Rakyat yang membentuknya sampai Dewan Perwakilan Rakyat baru menentukan lain.

14. Rapat pleno Dewan Perwakilan Rakyat menentukan jumlah biaya angket untuk satu tahun anggaran; jumlah itu dicantumkan dalam mata anggaran belanja Dewan Perwakilan Rakyat.

Sedangkan mekanisme pengajuan Hak Angket pada masa sekarang atau masa UU no 27 tahun 2009 yaitu:

1. Hak angket diusulkan oleh paling sedikit 25 (dua puluh lima) orang anggota DPR dan lebih dari 1 (satu) fraksi.

2. Pengusulan hak angket disertai dengan dokumen yang memuat sekurang-kurangnya:

a. Materi kebijakan dan/atau pelaksanaan undang-undang yang akan di-selidiki; dan

b. Alasan penyelidikan.

3. Usul menjadi hak angket DPR apabila mendapat persetujuan dari rapat paripurna DPR yang dihadiri lebih dari $1 / 2$ (satu perdua) jumlah anggota DPR dan keputusan diambil dengan persetujuan lebih dari 1/2 (satu per-dua) jumlah anggota DPR yang hadir.

4. DPR memutuskan menerima atau menolak usul hak angket.

5. Dalam hal DPR menerima usul hak angket DPR membentuk panitia angket yang terdiri atas semua unsur fraksi DPR dengan keputusan.

6. DPR, dalam hal DPR menolak usul hak angket, usul tersebut tidak dapat diajukan kembali.

7. Panitia angket dalam melakukan penyelidikan, selain meminta keterangan dari Pemerintah, dapat juga meminta keterangan dari saksi, pakar, organisasi profesi, dan/atau pihak terkait lainnya.

8. Dalam melaksanakan tugasnya, panitia angket dapat memanggil warga negara Indonesia dan/atau orang asing yang bertempat tinggal di Indone-sia untuk memberikan keterangan.

9. Warga negara Indonesia dan/atau orang asing wajib memenuhi panggilan panitia angket.

10. Dalam hal warga negara Indonesia dan/atau orang asing sebagaimana di-maksud pada ayat (2) tidak memenuhi panggilan setelah dipanggil 3 (tiga) kali berturut-turut tanpa alasan yang sah, panitia angket dapat 
memanggil secara paksa dengan bantuan Kepolisian Negara Republik Indonesia se-suai dengan ketentuan peraturan perundangundangan.

11. Panitia angket melaporkan pelaksanaan tugasnya kepada rapat paripurna DPR paling lama 60 (enam puluh) hari sejak dibentuknya panitia angket. Rapat paripurna DPR mengambil keputusan terhadap laporan panitia angket.

12. Apabila rapat paripurna DPR memutuskan bahwa pelaksanaan suatu undang-undang dan/atau kebijakan Pemerintah yang berkaitan dengan hal penting, strategis, dan berdampak luas pada kehidupan bermasyarakat, berbangsa, dan bernegara bertentangan dengan ketentuan peraturan per-undang-undangan, DPR dapat menggunakan hak menyatakan pendapat.

13. Apabila rapat paripurna DPR memutuskan bahwa pelaksanaan suatu un-dang-undang dan/atau kebijakan Pemerintah yang berkaitan dengan hal penting, strategis, dan berdampak luas pada kehidupan bermasyarakat, berbangsa, dan bernegara tidak bertentangan dengan ketentuan peratu-ran perundang-undangan, usul hak angket dinyatakan selesai dan rnateri angket tersebut tidak dapat diajukan kembali.

14. Keputusan DPR harus mendapat persetujuan dari rapat paripurna DPR yang dihadiri lebih dari $1 / 2$ (satu perdua) jumlah anggota DPR dan putusan diambil dengan persetujuan lebih dari $1 / 2$ (satu perdua) jumlah anggota DPR yang hadir.

15. Ketentuan lebih lanjut mengenai tata cara pelaksanaan hak angket diatur dengan peraturan DPR tentang tata tertib.

Dari uraian di atas, maka muncul pertanyaan bagaimanakah implementasi dan efektivitas hak angket dalam mengontrol kebijakan pemerintah?

\section{B. PEMBAHASAN}

\section{Implementasi Hak Angket Dalam Mengontrol Kebijakan Pemerintah.}

Sebagi salah satu contoh setelah bergulirnya UU tentang Hak angket tersebut pada masa orde lama telah diajukan hak angket. Pada sejarah ketatanegaraan Indone-sia, hak angket digunakan kali pertama pada 1950-an. Berawal dari usul resolusi RM Margono Djojohadikusumo agar DPR mengadakan angket atas usaha pemerintah memperoleh dan cara mempergunakan devisa. Maka kemudian dibentuklah Panitia Angket beranggotakan 13 orang, diketuai Margono, yang tugasnya menyelidiki un-tung rugi mempertahankan devi-sen-regime berdasar Undang-Undang Pengawasan Devisen 1940 dan perubahan-peruba-hannya.

Panitia Angket pada masa Kabinet Ali Sastroamidjojo-I (30 Juli 1953-12 Agus-tus 1955) ini mula-mula diberi waktu enam bulan, tetapi kemudian diperpanjang dua kali dan menyelesaikan tugasnya pada Maret 1956 pada masa Kabinet Burhanuddin Harahap (12 Agustus 1955-24 Maret 1956). Sayang, hasil 
kerja tim bersamaan deng-an terbentuknya kabinet hasil Pemilu 1955 (Kabinet AH Sastroamidjojo-II) itu nasib-nya tidak jelas.

Berbeda ketika masa orde baru, hak angket menjadi tak berdaya melawan kekuasaan yang otoriter. Meskipun pada masa Orde Baru, parlemen praktis dikuasai Golkar sebagai fraksi penopang pemerintah, usul penggunaan hak angket sempat lolos masuk dalam sidang pleno DPR 7 Juli 1980. Sebanyak 20 anggota DPR (14 dari FPDI dan 6 dari FPP) menan-datangani usul penggunaan hak angket yang kemudian diserahkan R Santoso Danuseputro (FPDI) dan HM Syarkawie Basri (FPP) kepada Ketua DPR kala itu, Daryatmo, pada 5 Juli (www.wikipedia.org akses 20-02-2011).

Para pengusul angket tidak puas atas jawaban Presiden Soeharto menyangkut kasus $\mathrm{H}$ Thahir dan Pertamina yang disampaikan Mensesneg Sudharmono dalam si-dang pleno DPR 21 Juli 1980, menanggapi interpelasi atau hak bertanya yang uniknya dilakukan tujuh anggota FKP sendiri. Usul angket tentang Pertamina tersebut dican-tumkan rencana pembentukan Panitia Angket yang terdiri atas 14 orang dengan 24 anggota pengganti, plus sejumlah tenaga ahli yang khusus dipekerjakan untuk itu, dengan anggaran waktu itu sebesar Rp 108 juta. Panitia angket diprogramkan bekerja selama satu tahun, dan setiap bulan bersidang sedikitnya empat kali dan sebanyaknya delapan kali. Jadi dalam satu tahun mereka bersidang hingga sekitar 75 kali.

Reaksi keras pun muncul, terutama dari kalangan anggota FKP dan Fraksi ABRI yang menyoal perlunya menggunakan hak angket. Nasib selanjutnya pun sangat jelas: hak angket ditolak. Angket mentok di sidang pleno DPR. Setelah itu, hak ini nya-ris tak pernah terdengar lagi gaungnya hingga rezim Orde Baru tumbang pada 1998.

Kerajaan Soeharto runtuh pada tahun 1998, maka mulai ada pergerakan di parlemen. Mulai mengamandemen Undang-Undang Dasar Negara Republik Indonesia hingga hak-hak parlemen yang selama 32 tahun terpasung mulai berdunyut kem-bali. Pasca reformasi, penggunaan hak angket kembali digulirkan. Itu terjadi ketika DPR mencium keterlibatan Presiden Abdurrahman Wahid dalam penyalahgunaan uang Yayasan Dana Kese-jahteraan (Yanatera) Bulog. Hak angket digunakan untuk menyelidiki penyelewengan dana Bulog serta bantuan dana dari Sultan Brunei atau yang lebih dikenal dengan istilah Bulog-gate dan Bruneigate (Anton Pranoto, 2010: 8).

Tidak seperti sebelumnya, hak angket yang dipicu keluarnya memorandum Gus Dur untuk membubarkan parlemen itu berujung pada impeachment presiden. Pada periode pertama masa jabatan Presiden Susilo Bambang Yudhoyono (SBY), hak angket pernah dicoba digulirkan atas sejumlah kasus, di antaranya menyangkut kenaikan harga BBM yang mengundang reaksi maliasiswa, masalah impor beras 2006, penyelenggaraan ibadah haji 2008, dan ruwetnya daftar pemilih tetap (DPT) Pemilu 2009. Namun, usaha tersebut hanya menghasilkan keputusan normatif.

Ketua DPR HR Agung Laksono ketika pidato di depan Sidang Paripurna Pembukaan Masa Persidangan I Tahun Sidang 2009-2010, pertengahan Agustus lalu mengaku bahwa DPR masih terus berusaha untuk menuntaskan beberapa hak DPR 
yang sedang dalam proses. Beberapa di antaranya menuntaskan hak angket menyangkut penyelenggaraan ibadah haji $1429 \mathrm{H} / 2008$, hak angket DPT, dan hak angket menyangkut kebijakan Pemerintah menaikkan harga BBM. Tapi belum lagi itu ditun-taskan, kini menggelinding usulan penggunaan hak angket soal dana talangan Bank Century Rp 6,7 triliun menjadi buah bibir dari berbagai kalangan politikus di DPR.

Belajar dari kasus-kasus sebelumnya, hak angket nampak hanya menjadi sebuah keputusan normatif tanpa ada solusi yang dapat diberikan. Padahal peraturan Tata Tertib DPR menegaskan, hak angket digunakan untuk menyelidiki "kebijakan pe-merintah yang penting dan strategis serta berdampak luas pada kehidupan berma-syarakat dan bernegara yang diduga bertentangan dengan peraturan perundang-undangan".

Sehubungan dengan skandal Bank Century, kebijakan pemerintah "menyelamatkan" Bank Century dengan sendirinya dapat menjadi objek Hak Angket DPR karena berdampak luas pada kehidupan bermasyarakat dan bernegara, apalagi kebijakan itu juga berkaitan dengan keuangan negara. Namun, apakah kebijakan itu benar-benar bertentangan dengan UU sebagaimana dugaan DPR, inilah yang harus "dibukti-kan" melalui penggunaan hak angket itu. Carut-marut pengucuran dana talangan Bank Century yang menyeret keter-libatan beberapa pejabat negara, seperti guber-nur BI dan Menkeu, mendorong sejumlah anggota Dewan menggulirkan hak angket untuk mengurai benang kusut tersebut. Penting bagi DPR menggali keterangan ahli dan semua pihak terkait dengan aliran dana dan masalah lainnya yang terkait dengan "penyelamatan" Bank Century. Harapannya dengan penggunaan hak angket muncul konklusi yang lebih objektif, bukan asal kritis. Sebab, orientasi angket menyelidiki dan mencari solusi. Keingintahuan DPR bukan sebatas mendengar apologi pemerintah, melainkan menguak lebih jauh ada apa sebenarnya di balik kebijakan pe-merintah terhadap pengawasan bank-bank selama ini.

Hasil audit dari Badan Pemeriksa Keuangan (BPK) menyangkut Bank Century dapat digunakan (atau tidak digunakan) oleh panitia angket DPR. Nantinya, DPR da-pat saja berpendapat lain dengan BPK. Dengan kata lain, bila hasil audit BPK berke-simpulan aliran dana pemerintah ke Bank Century sudah sesuai dengan prosedur, kesimpulan itu dapat dikesampingkan oleh DPR. Apalagi Wapres Boediono memiliki peran terkait pencairan dana $\mathrm{Rp} \mathrm{6,7} \mathrm{triliun} \mathrm{saat} \mathrm{dirinya} \mathrm{menjadi}$ Gubernur BI. Pada titik inilah kehadiran Panitia Hak Angket DPR untuk menguak persoalan seputar penyelamatan Bank Century menjadi amat penting dilakukan.

Persoalan Bank Century menjadi semakin menarik sejak 138 anggota Dewan Perwakilan Rakyat (DPR) secara resmi menyerahkan usulan hak angket kepada pim-pinan DPR (12/11/2009). Jumlah anggota yang menandatangani usulan tersebut di-kabarkan terus ber-tambah.

Wapres Boediono, yang namanya terseret dalam kasus ini, pernah menyatakan bahwa penggunaan angket adalah hal yang wajar dalam sistem demokrasi (13/11/2009). Maka banyak pihak berharap Hak Angket DPR untuk kasus Century 
berhasil dilaksanakan, tidak kempis di tengah jalan seperti penggunaan hak angket pada masa sebelumnya. Modal kejujuran dan kesungguhan perlu untuk dipegang oleh DPR selaku pemilik Hak Angket.

\section{Efektifitas Hak Angket DPR dalam mengawasi kebijakan Pemerintah}

Hak angket merupakan salah satu hak konstitusional Dewan Perwakilan Rak-yat (DPR). Namun, dalam praktiknya upaya penggunaan hak angket hanya menjadi mission impossible. Buktinya, sejak digulirkan pertama kali pada tahun 1950an sam-pai sekarang Hak angket tidak menemukan titik muara seperti apa yang telah termak-tub dalam UU No 6 tahun 1954 tentang Hak Angket maupun UU No 27 Tahun 2009. Hak angket seperti hanya merupakan pelengkap dari parlemen dan mungkin saja hanya merupakan permainan politik dari partai-partai yang menduduki kursi wakil rakyat tersebut.

Mengapa begitu sulit menggunakan hak angket? Sebetulnya, sebagaimana dinyatakan pada bagian awal, hak angket merupakan salah satu hak konstitusional DPR. Pasal 20A UUD 1945 menyatakan, DPR memiliki fungsi legislasi, anggaran, dan penga-wasan. Untuk melaksanakan fungsi tersebut, DPR mempunyai hak interpelasi, hak angket, dan hak menyatakan pendapat. Bahkan, demi mendukung hak konstitusional itu, setiap anggota DPR mempunyai hak mengajukan pertanyaan, menyampaikan usul dan pendapat, serta hak imunitas.

Kandasnya beberapa kali upaya usulan menggunakan hak angket membuktikan bahwa DPR gagal memaknai arti penting hak konstitusional yang diberikan oleh UUD 1945. Bagaimanapun, hak angket adalah salah satu alat yang mesti digunakan untuk mengkritisi kebijakan pemerintah. Apalagi kalau kebijakan pemerintah memberikan dampak luas terhadap kehidupan masyarakat. Penggunaan hak itu menjadi sebuah keniscayaan ka-lau kebijakan pemerintah diduga bertentangan dengan peraturan perundang-undangan.

Kalau kegagalan itu diletakkan dalam sistem pemerintahan, praktik sistem presidential Indonesia sedang berada dalam jebakan parlementer. Maksudnya, mayo-ritas kekuatan politik di DPR lebih berperan sebagai pendukung kebijakan pemerin-tah ketimbang menjadi mitra kritis. Setidaknya, kegagalan usulan hak angket sebe-lum-sebelumnya memperkuat anggapan yang berkembang selama ini bahwa DPR sulit (tidak mungkin) keluar dari kepentingan politik pemerintah. Artinya, penilaian bahwa DPR merupakan tukang stempel kebijakan pemerintah sulit dimentahkan.

Hal ini dibuktikan dengan lebih dari 70 persen anggota DPR periode 20092014 berasal dari partai yang berkoalisi dengan pemerintali. Koalisi ini juga secara dominan "menguasai" kursi ketua komisi-komisi. Sembilan dari sebelas kursi ketua komisi diduduki wakil rakyat dari partai koalisi. Akibatnya, meskipun secara legalformal kita berada dalam legislative heavy, secara praksis diperkirakan kita telah ber-alih ke executive heavy. Ibarat berada di kandang macan, kita sekarang berada di kan-dang yang macannya sudah dicabuti giginya. Macannya tetap sebagai macan, namun telah kehilangan kekuatannya. Bahkan, tidak lagi memiliki kemampuan 
mengunyah makanan. Itulah kira-kira analogi bagi DPR sekarang yang berada dalam atmosfer executive heavy.

Oleh karenanya, bukan ayat undang-undang yang diubah, sehingga lokus kewenangan berubah, melainkan pengaruh terhadap orang di dalamnya yang berubah dari potensial sebagai spoiler menjadi suporter pemerintah. Dari potensi penentang menjadi pendukung. Adanya pengaruh yang jauh meresap ke legislatif tersebut, dapat diartikan, Presiden Susilo Bambang Yudhoyono telah berhasil melakukan hegemoni terhadap ruang kekuasaan lain. Koalisi besar bermakna "penyatuan kembali" sepa-ration of power.

Pada posisi kondisi executive heavy seperti ini, apa yang akan terjadi dalam berne-gara ke depan? Pertama, DPR yang isinya didominasi "orang-orang presiden" diprediksi tidak mampu melaksanakan fungsi pengawasan. Koalisi besar akan membelenggu wakil rakyat melalui fraksi-fraksi sebagai kepanjangan tangan. Akibatnya, kemauan membela kepentingan rakyat semakin lemah, kecerdasan dalam menjalankan tugas-tugas sebagai legislator menjadi tumpul, serta simpati dan empati ter-hadap kesulitan rakyat tak lebih sekadar polesan citra. Kondisi ini memunculkan pesimisme. Pada saat hegemoni belum terjadi, DPR telah memperlihatkan kelemahan, seperti interpelasi lumpur Lapindo yang layu sebelum berkembang pada pertengahan 2007, rontoknya usulan penggunaan hak angket untuk menyelidiki pelang-garan dalam penunjukan ExxonMobil Ltd sebagai pemimpin operator lapangan mi-nyak Blok Cepu pada Juni 2006, dan gagalnya hak angket impor beras, Januari 2006. Setelah era hegemoni ini, catatan kelemahan diprediksi semakin panjang. Kedua, DPR tidak akan mampu menilai dan menyaring kritis RUU inisiatif pemerintah. Ini kurang lebih menjadi sama seperti DPR era Orde Baru. DPR tak lebih sebagai lembaga yang memuluskan keinginan pemerintah.

Ini akan berakibat produk legislasi yang dihasilkan cenderung akan kental dengan kepentingan kelompok atau golongan. Saat DPR belum terhegemoni, produk undang-undang seperti ini masih ada yang lolos, misalnya UU No 38 Tahun 2004 tentang Jalan yang isinya menetapkan bahwa tarif tol secara otomatis akan naik setiap dua tahun. Setelah terhegemoni, UU yang aneh serta memberatkan rakyat seperti itu berpotensi lebih banyak muncul. Maka selanjutnya, diprediksi banyak anggota DPR yang kehilangan kemampuan "mengunyah makanan". Mereka kehilangan kemampu-an melaksanakan fungsi pengawasan dan legislasi. Tegasnya, DPR 2009-2014 akan didominasi oleh manusia instrumental, yang berperan sebagai alat yang memuluskan berbagai kebijakan pemerintah. Executive heavy seperti ini jauh lebih berbahaya dari sebelumnya. Penyatuan kekuasaan ini tersamar dalam separation of power secara legal-formal. Akibatnya, otoriterisme yang amat mungkin semakin dekat, terbungkus dalam sistem yang terlihat demokratis. Secara perlahan ke-ramaian bernegara akan berakhir dan menjadi hening. Pada saatnya, sunyi, menjadi hal yang paling mengeri-kan. Posisi yang amat kuat berpotensi tidak hanya menggerus segenap suara kritis, juga menjadikan suara kritis tersebut aneh dan konyol. 
Banyak pihak mengatakan bahwa civil society dapat memerankan diri sebagai pressure group agar DPR kembali bergairah melaksanakan kebebasannya sebagai wakil rakyat. Meskipun agak pesimistis, karena civil society tidak memiliki instrumen yang efek-tif untuk melakukan hal itu, namun sehelai harapan tetap perlu digantung-kan. Harapan tipis itu kiranya dapat kita sangkutkan pada wakil rakyat yang partai-nya tidak tergabung dalam koalisi pemerintah, yaitu, PDI-P, Gerindra, dan Hanura, meskipun ketiga partai ini tidak terlalu besar memberikan harapan.

Lebih memprihatinkan lagi, bisa jadi, bagi beberapa anggota hak angket digunakan untuk memperkuat bargaining dengan pemerintah. Pada konteks tersebut, sebagian anggo-ta DPR cuma membonceng hak angket untuk dijadikan alat bargainning politik atau uang. Buktinya, banyak anggota DPR yang menggebu-gebu pada awal pengajuan hak angket, namun akhirnya berubah sikap. Kegagalan-kegagalan hak angket terdahulu dan mandeknya hak angket Century dapat memperkuat pendapat tersebut.

Selain besarnya godaan bagi anggota DPR, kesulitan lain untuk mendorong penggunaan hak angket adalah manuver pemerintah. Sejak semula, sudah ada upaya untuk merangkul semua kekuatan politik di DPR. Upaya itu dilakukan dengan menempatkan wakil partai politik untuk menjadi anggota kabinet. Dengan pembagian itu, baik langsung maupun tidak langsung, partai politik yang punya kursi di kabinet akan kesulitan bersikap kritis terhadap kebijakan pemerintah. Sejauh ini, sikap "abu-abu" cenderung dipertontonkan oleh F-PPP, F-PAN, dan F-KB (Toto Sugiarto, 2009).

Cara pandang yang lebih sederhana, kalau partai politik sudah mendapatkan kursi di kabinet, berarti partai bersangkutan sudah menyatakan bergabung dan menundukkan diri untuk mendukung kebijakan pemerintah. Pendapat ini menjadi makin kuat karena kebe-radaan fraksi (sebagai perpanjangan kepentingan partai politik) begitu dominan dalam pro-ses pengambilan keputusan di DPR. Karena posisi demi-kian, fraksi selalu dijadikan alat oleh berbagai kepentingan untuk melumpuhkan se-gala macam pemikiran kritis yang berkembang di DPR.

Untuk memperbaiki praktik ketatanegaraan ke depan, anggota DPR yang akan menggunakan hak angket perlu mengubah cara yang ditempuh selama ini. Salah satu caranya, mengelaborasi secara mendalam tentang makna "kebijakan pemerintah yang penting dan strategis serta berdampak luas pada kehidupan bermasyarakat dan bernegara yang diduga bertentangan dengan peraturan perundang-undangan". Kalau itu bisa dilakukan, upa-ya setiap pengusul hak angket akan semakin mendapai tempat di mata publik.

Pada akhirnya hak angket lebih cenderung bersifat politis. Para pemegang hak ter-sebut hanya cari aman saja, baik berlindung di ketiak pemerintah agar mendapat jatah kursi kabinet, maupun berlindung atas nama rakyat untuk menarik simpati, se-hingga pemilu selanjutnya dapat meraih suara yang diharapkan bisa lebih mending-krak perolehan suara mereka. Politik dan parlemen sesuatu yang tidak bisa dipisah-kan, keduanya berbanding lurus. Semakin banyak anggota parlemen, maka kekuatan politis akan semakin kuat. Seperti hal-nya pemerintahan 
pada periode 2009-2014, kekutan politik begitu besar baik pada pemerintah maupun parlemen. Kedua lembaga negara tersebut berasal dari partai yang sama sehingga ada semacam keraguan dari DPR untuk memeriksa bahkan mengawasi pun terkesan hanya setengah-setengah.

Efektif atau tidak hak angket selama ini jelas mendapat penafsiran yang berbeda. Pemerintah akan beranggapan bahwa setiap kebijakan yang mereka ambil telah sesuai dengan Undang-Undang, sehingga tidap perlu dipertanyakan lagi dan tidak perlu adanya hak angket. Sedangkan DPR akan beranggapan bahwa mereka sudah melakukan sesuai dengan Undang-Undang yang berlaku, jadi hak angket telah efektif normatif.

\section{KESIMPULAN DAN SARAN}

\section{Kesimpulan}

Mekanisme pengajuan hak angket terbagi menjadi dua yakni menurut UU No 6 Tahun 1954 dan UU No 27 Tahun 2009. Berdasarkan UU no 6 Tahun 1954 menegaskan usul untuk mengadakan angket dimajukan dengan tertulis oleh sekurang-kurangnya 10 orang anggota Dewan Perwakilan Rakyat, yang berujung pada kewenangan Yustisial atau meng-adili oleh Dewan Perwakilan Rakyat. Sedangakan berdasar-kan UU No 27 Tahun 2009 mengatur mekanisme pengajuan hak angket yaitu hak angket diusulkan oleh paling sedikit 25 (dua puluh lima) orang anggota DPR dan lebih dari 1 (satu) fraksi. Pengusulan hak angket disertai dengan dokumen yang memuat sekurang-kurangnya: (1) materi kebijakan dan/atau pelaksanaan undang-undang yang akan diselidiki; dan (2) alasan penyelidikan. Usul menjadi hak angket DPR apabila mendapat persetujuan dari rapat paripuma DPR yang dihadiri lebih dari $1 / 2$ (satu perdua) jumlah anggota DPR dan keputusan diambil dengan persetujuan lebih dari $1 / 2$ (satu perdua) jumlah anggota DPR yang hadir. DPR memutuskan menerima atau menolak usul hak angket. Kemudian berakhir pada hak untuk mengajukan pen-dapat. Hal inilah yang terkesan hak angket pada masa sekarang kurang mempunyai tajinya. Meskipun zaman dulu juga tidak begitu berpengaruh.

Pada sejarah ketatanegaraan Indonesia, hak angket digunakan kali pertama pada 1950-an. Berawal dari usul resolusi RM Margono Djojohadikusumo agar DPR mengadakan angket atas usaha pemerintah memperoleh dan cara mempergunakan devisa. Sayang, hasil kerja tim bersamaan dengan terbentuknya kabinet hasil Pemilu 1955 (Kabinet Ali Sastroamidjojo-II) tidak nampak jelas. Masa Orde Baru, parlemen praktis dikuasai Golkar sebagai fraksi penopang pemerintah, usul penggunaan hak angket sempat lolos masuk dalam sidang pleno DPR 7 Juli 1980. Para pengusul angket tidak puas atas jawaban Presiden Soeharto menyangkut kasus H. Thahir dan Perta-mina yang disampaikan Mensesneg Sudharmono dalam sidang pleno DPR 21 Juli 1980. Nasib selanjutnya pun sangat jelas; hak angket ditolak. Angket mentok di sidang pleno DPR. Setelah itu, hak ini nyaris tak pernah terdengar lagi gaungnya 
hingga rezim Orde Baru tumbang pada 1998. Pasca reformasi, peng-gunaan hak angket kem-bali digulirkan. Tidak seperti sebelumnya, hak angket yang dipicu keluarnya memo-randum Gus Dur untuk membubarkan parlemen itu berujung pada impeachment presiden. Pada periode pertama masa jabatan Presiden Susilo Bambang Yudhoyono (SBY), hak angket pernah dicoba digulirkan atas sejumlah kasus, di antaranya me-nyangkut kenaikan harga BBM yang mengundang reaksi mahasiswa, masalah impor beras 2006, penyelenggaraan ibadah haji 2008, dan ruwetnya daftar pemilih tetap (DPT) Pemilu 2009. Namun, usaha tersebut hanya menghasilkan keputusan normatif.

Pada akhirnya hak angket lebih cenderung bersifat politis. Para pemegang hak ter-sebut hanya cari aman saja, baik berlindung di ketiak Pemerintah agar mendapat jatah kursi kabinet, maupun berlindung atas nama rakyat untuk menarik simpati, se-hingga pemilu selanjutnya dapat meraih suara yang diharapkan bisa lebih mending-krak perolehan suara me-reka. Politik dan parlemen sesuatu yang tidak bisa di-pisahkan. Keduanya berbandingg lu-rus. Anggota parlemen sernakin banyak maka kekuatan politis akan sernakin kuat. Seperti halnya pemerintahan pada periode 2009-2014, kekutan politik begitu besar baik pada pemerintah maupun parlemen. Kedua lembaga negara tersebut berasal dari partai yang sama sehingga ada semacam keraguan dari DPR untuk memeriksa bahkan mengawasi pun terkesan hanya sete-ngah-setengah. Efektif atau tidak hak angket selama ini jeias mendapat penafsiran yang berbeda. Pemerintah akan beranggapan bahwa setiap kebijakan yang mereka ambil telah sesuai dengan Undang-Undang, sehingga tidap perlu dipertanyakan lagi, tidak perlu adanya hak angket. DPR akan beranggapan baliwa mereka sudah melaku-kan sesuai dengan Undangg-Undang yang berlaku, jadi hak angket telah efektif nor-matif.

\section{Saran}

Pemerintah, Dewan Perwakilan Rakyat, maupun Rakyat sendiri memegang peranan penting dalam membangun dan membetuk negara ini menjadi lebih baik lagi. Pemerintah dalam membuat kebijakan bagi negara senantiasa memperhatikan ke-pentingan rakyat. Bagaimanapun para pejabat yang kini mengisi kursi pemerintahan awalnya dipilih rakyat. Sudah seharusnya apapun yang dilakukan pemerintah untuk kepentingan seluruh rakyat Indonesia bukan untuk segelintir orang saja. Kebijakan-kebijakan yang menyangkut hajat hidup orang banyak lebih diperhatikan agar tidak menjadi polemik di kalangan pusat.

Sementara Dewan Perwakilan Rakyat Republik Indonesia, baik dari partai manapun, mereka adalah penjelmaan kedaulatan seluruh rakyat Indonesia. Tidak ada lagi warna biru, merah, putih, kuning, hijau, oranye, tapi mereka adalah merah putih. Seharusnya tak ada lagi kepentingan golongan di tengah-tengah Senayan. Oposisi maupun pemerintah bekerja sama demi negara demi rakyat. Singkirkan permainan politik ketika duduk membahas rakyat. Kinerja ditingkatkan, implementasi Undang-Undang dalam menjadi mitra pemerintah hendaknya dilakukan dengan atas nama rakyat. Tegur keras jika pemerintah melakukan 
penyelewengan terhadap pelaksana-an Undang-undang, atau ketika muncul kebijakan pemerintah yang merugikan rakyat. Keberanian Dewan Perwakilan Rakyat dalam mengontrol dan mengawasi pemerin-tah akan berujung pada negara yang diharapkan rakyat, yaitu negara yang sejahtera.

\section{DAFTAR PUSTAKA}

\section{JURNAL DAN MAKALAH}

Abdul Rahim, Kekuasaan Dalam Negara Hukum, www,unisma.ac.id/hukum (tanggal akses 3 September 2010)

Anton Pratono, Teori Kekuasaan, google.com/article_oleh_anton_pratono (tanggal akses 3 September 2010)

Hadari Nawawi, 1991. Metodologi Penelitian Dalam Bidang Sosial. Pontianak: GUMP http://top 1 Qheadline.com/home http://www.beritaindonesia.co.id/

Suara Pembaruan, Rabu, 11 November 2009 Oleh: Toto Sugiarto

Wikipedia, (http://www.wikipedia. org) Diakses tanggal 20 Februari 2011

\section{PERATURAN PERUNDANG-UNDANGAN}

Undang-Undang Dasar 1945

Undang-Undang No 27 Tahun 2009 Tentang Iviajelis Permusyawaratan Rakyat, Dewan Perwakilan Daerah, Dewan Perwakilan Rakyat, dan Dewan Perwakilan Rakyat Daerah

Undang-Undang No 6 Tahun 1954 Tentang Hak Angket 
